\title{
Arbuscular Mycorrhizal Fungi : Diversity and Its Impact with Abiotic Factors in Phoenix dactylifera L. of Kachchh Region, Gujarat, India
}

\author{
Dipika J. Dalal', Hitesh Solanki \\ Department of Botany, Gujarat University, Ahmedabad, Gujarat, India
}

\begin{abstract}
Article Info

Volume 8, Issue 2

Page Number : $125-135$

Publication Issue

March-April-2021

Article History

Accepted : 10 March 2021

Published : 18 March 2021

Mycorrhizal diversity of non-agricultural sites from Madhapar, Reladi and Anjar region of Kachchh regions were studied. Date palm is an economically important plant in dry lands of the world approach towards an investigation of AM fungi diversity and their association with the date palm in Kachchh. This is important to understand the root colonization, spore analysis and spore density in the study. The study is about the composition of AM fungi at an agricultural site. Also to understand the relevance of species composition and their relationship with abiotic factors. In the present work soil of agricultural field has been taken into consideration to understand the relevance.

Keywords: Date Palm, Arbuscular Mycorrhizal Fungi, Spore Analysis, Root Colonization.
\end{abstract}

\section{INTRODUCTION}

Soil microorganisms play highly beneficial to the harmful role for plant growth and survival. There are several groups of beneficial rhizosphere microorganisms. Some engaged in well developed symbiotic interactions in which particular organs are formed such as mycorrhiza and root nodules, whilst others develop from fairly loose association with the root (Brockwell et al, 1995).

Microbial activity in the rhizosphere is the major factor that determines the availability of nutrients to plants and has a significant influence on plant health and productivity. It is very important to understand the basic principles of rhizosphere microbial ecology, including the function and diversity of the micro- organisms that reside there. In this context, it is important to use a broad definition of the rhizosphere to include the rhizosphere soil, the volume of soil adjacent to and influenced by the root, the root surface (or rhizoplane) and the root itself which includes the cells of the root cortex where invasion and colonization by endophytic microorganisms has occurred (Kennedy 1998).

Arbuscular mycorrhiza-forming fungi (AMF) are obligate biotrophs that require the host plant to complete its life cycle. The fungus colonizes the root cortex and forms intracellular structures called Arbuscules (from the Latin "Arbusculum", meaning bush or little tree) where the exchange of nutrients between the partners takes place. The extracellular hyphal network spreads widely into the surrounding 
soil, thereby reaching out of the nutrient depletion zone and improving the supply of inorganic nutrients, especially phosphate and nitrate (Smith et al, 2011).

Photosynthates and carbohydrates are received from the host plants by the hetero-trophic fungi. These fungi are classified in the order Glomales of Zygomycota, but in recent classification, these were classified as a different Phylum Glomeromycota. In the natural ecosystem fungi are the principle component of the flora of the rhizosphere, (Peterson et al, 1985) but, are influenced by biotic and abiotic factors (Mohammad, et.al, 2003). The diversity of AM species depends on the ecosystem itself, (Helgason, et.al, 1998) agricultural practices and soil environment (e.g. Disturbance), also the density of spores, length of mycelia, number of species (Dodd, J.C., 2000). AM Fungi is associated with $90 \%$ of all plant species in nature (Wang \& Qiu, 2006). The uptake of non-mobile nutrients such as $\mathrm{P}$ is the main benefit to plants promoted by the fungi, results in higher growth rates and enhances nutrition (Smith \& Read, 2008).

Mycorrhizal fungi increase the yield of agricultural plants, especially in soils with low fertility. Such an increase may be due to the increase in the absorption of the roots as a result of the wide extension of fungus mycelium in the soil (Fitter AH. 1985). Date palms are considered very decisive to the ecosystem in an arid region as they guard the surrounding vegetation against desertic influence and providing an adequate microclimate for underbrush crops. One of the most significant functions about AMF is they protect plants against the environmental stress, such as soil salinity (Guissou T, et al 2001., Martin F. 1985), drought (Inoue et al, 2009) and pathogens (Newsham et al 1995b; Klironomos 2000; Maherali and Klironomos 2007; Sikes et al 2009).

Phoenix dactylifera L. tree and its products are regarded as vegetables with health benefits and have been employed traditionally to remedy many pathological conditions. Date fruits are a significant component of the diet in most of the Arab countries with low cost. The importance of the date in human nutrition comes from its rich composition of carbohydrates (70-80\%), salts and minerals,dietary fiber, vitamins, fatty acids, amino acids and protein. Research proves that when dates are eaten alone or as mixed meals with yogurts they have low glycemic indexes. Recently, date pit powders are also marketed and are a source of choice for people preferring a noncaffeinated coffee with coffee-related flavor. The fleshy tissues of dates contain $0.2-0.5 \%$ oil, while the seed contains $7.7-9.7 \%$ oil. Since, Kachchh is a semiarid region and date palm plays a key role in its economy this work has been carried out to assess various species associated with Phoenix dactylifera in this region. It requires dry hot climate for growth and development of fruits. In the arid region, crop production is a risky preposition, where date palm cultivation contributes in achieving food security, high nutritive value food, crop diversification, desertification control, income generation and foreign exchange earnings (Singh and Murlidharan, 2016).

\section{METHODS AND MATERIAL}

\section{Collection of the sample:}

The soil sample were collected from the surface, and at the depth of $30 \mathrm{~cm} \& 60 \mathrm{~cm}$. The Rhizospheric soil sample was collected with the help of shovel and trowel and was collected in the zip-lock bags. The rhizospheric soils were collected for the screening for mycorrhizal colonization. The collection bags were closed airtight in to maintain the moisture and freshness of the sample. All the collection bags were labeled mentioning name of the plant, date, place and other important information. 

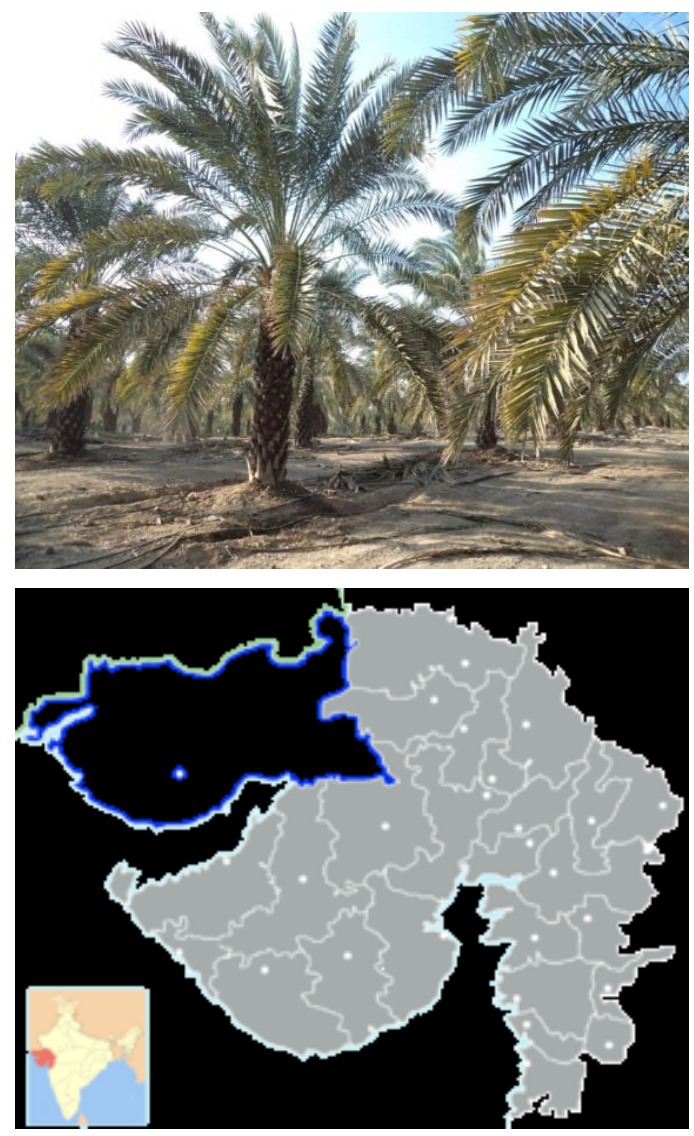

Processing of the sample in the lab for root colonization percentage

The plant root hair were washed in running tap water and were cut into small pieces of around 0.5 to $1 \mathrm{~cm}$ in length. Then these cut root hair were treated with $10 \%$ $\mathrm{KOH}$ solution and then were neutralized with $10 \%$ HCL solution. Neutral-ized pieces were kept for staining in Lactophenol Cotton blue for around 24 hour. After 24 hours the extra stain was removed with the help of Lacto phenol and the samples were ready to screen under the microscope. The treated root piece were put on slide with mounting medium lacto phenol and covered with cover slip and this prepared slide was then screened under the microscope for the calculation of colonization percentage (Phillips, J.M. and Hayman D.S.1970).

\section{Spore Isolation and Identification:}

Spore extraction and counting were carried out from soil with the help of wet sieving and decanting technique (Gerdemann and Nicolson 1963). In this technique different sieves were used. $100 \mathrm{~g}$ rhizospheric soil was taken in beaker and dis-solved in $1000 \mathrm{ml}$ distilled water and then kept for at least $1 / 2$ hour so that soil particle's may settle down. After $1 / 2$ hour these water was slowly poured in the sieves arranged for filter. This procedure was repeated for three times. Then filter of 500mic, $105 \mathrm{mic}$, and $45 \mathrm{mic}$ was taken on Whatman filter paper no.1 with the help of funnel. This filter paper was then dried properly. The sample was then placed on the slide with the help fine brush. Subsequently, permanent preparations were made with alcohol and polyvinylglycerol (PVLG) and PVLG with Melzer's solution according to Schenck and Pérez (1990). The isolated spores were measured under light microscope. Characteristics such as number of spore layers, ornamentation of outer layers, shape and type of hyphal attachments and sporogenous cells, and the wall layer reactions to Melzer's reagent were also recorded. Junppomen, 2001.

\section{RESULTS AND DISCUSSION}

The present study confirms the association of AM fungi in the rhizosphere of date palm. Variation in vesicular and arbuscular content was observed in all the three Rhizospheric soil samples studied. Sample shows highest root colonization percentage. Root colonization percentage of sample 1 is moderate and sample 2 and sample 3 is good.

\section{IV.CONCLUSION}

As observed in all the three samples Glomus mosseae was predominant species. Scutellospora, Acualospora and Gigaspora were also recorded in all the samples. Whereas Glomus caledonium was recorded only in Sample 1 and sample 3,Glomus fasiculatum was recorded in Sample 1 and Sample 2.Gigaspora ramisporophora were recorded in Sample 2 and Sample 3, Gigaspora candida was also recorded in Sample 2 and Sample 3, Gigaspora albida were 
recorded in Sample 1 and Sample 3. Rich diversity was recorded in Sample 3 namely Glomus formosanum, Sclerocystis, Glomus monosporum, Glomus aggregatum, and Glomus caledonium.

The abundance of spores recorded is very low compared to that found by Bouamri (2006) in Tafilalet's soils (2080 spores/100g of soil). Work conducted on the date palm rhizosphere of Saudi Arabia (Mohamed et al, 2010) has shown that the density of spores was 58.3 to 82.3 spores $/ 15 \mathrm{~g}$ of soil (from 388.66 to $54866 / 100 \mathrm{~g}$ of soil). The mean spore densities measured in palm grove rhizospheres reached 812 spores /100 g of soil and was found comparable to spore densities registered under similar habitats associated with other hosts, e.g. argan trees (Argania spinosa (L.) Skeels) from south-west Morocco (900 to 2080 spores/100g of soil) (Nouaim, 1994) and Acacia albida Del. in Senegal (775 to 1240 spores/100g of soil) (Diop et al, 1994).

Morphological diversity of AM fungi in the studied habitats is supposed to be underestimated and the actual number of endomycorrhizal species could be higher. This underestimation could be due to the small number of soil samples analyzed. Bouamri (2010) reported the presence of 10 species in the date palm rhizosphere of Tafilalat (five species belonging to the genus Glomus, three Acaulospora and two Scutellospora). In soils oases of Saudi Arabia, 25 species were detected: 18 species belong to the genus Glomus, two species of the genera Scutellospora and Racocetra and one species of Acaulospora, Paraglomus and Ambiospora (Mohamed Al-Yahya'ei and al, 2011). In the Arabian Peninsula (Arabian desert), Symanczik et al (2014) presented the characteristics of four species of AMF recovered in the rhizosphere of date palm, namely Claroideoglomus drummondii, Diversispora aurantia Diversispora spurca and Funneliformis africanum. In semi-arid areas of Jaipur (India), four genera represented by 11 species have been reported: Gigaspora, Glomus, Scutellospora,
Entrophosphora and Sclerocystis (Sharma et Gheek Batra, 2014). Species of the genus Gigaspora are considered best suited for this kind of habitats subject to drought and soil salinity (Muthukumar and Udaiyan, 2002; Fa-doua Sghir et al, 2015).

The soil analysis revealed strong alkaline soil.

Intraradical hypha, vesicles, and arbuscules were detected in all date palm root samples from the Rhizosphoric soil surveyed. Root colonization reached between 30 and $74 \%$. The highest root colonization was observed in the Sample 1 site. At the opposite extreme, the lowest level of root colonization was observed in the Soil of Sample 2. Similar to root colonization, significant differences were observed between sites for spore density parameter At the Sample 1site, spore density reached 115 spores/100 g of soil whereas spore density reached 98 spores/100 $\mathrm{g}$ of soil at the Sample 2 site and 251/100 g of soil at Sample 3.

Fourteen distinct AMF species were isolated from the three palm grove sites. The genus Glomus was represented by 6 species: Glomus mosseae (Nicol and Gerd.) Gerd.and Trappe,G. fasciculatum Gerd. And Trappe emend. Walker and Koske, G.formosanum, G.aggregatum Schenck and Smith emend. Koske, G.caledonium G.monosporum. Three Gigaspora species: Gigaspora ramisporophora . Gigaspora candida , Gigaspora albida one Acaulospora species, one Scutellospora and one Sclerocystis species.Glomus mosseae were the most abundant and frequently observed AMF when Glomus aggregatum species showed up respectively at only one collecting site.

This shows that the soil was Moderately alkaline. The bulk density of all the three samples are respectively $1.20,1.25,1.16 \mathrm{~g} / \mathrm{cm} 3$. Water holding capacity observed in sample 1 was $90.8 \%$, sample 2 was $89.8 \%$ and sample 3 was $90.9 \%$ respectively. In a recent 
paper, studies show that, Kutch provides suitable having adequate aeration (12\%) with a bulk density of factors like a well-drained, deep, sandy type of soil $1-1.5 \mathrm{~g} / \mathrm{cm} 3$ and water holding capacity of at least 15\%. (J. J. Shah , 2015)

Table 1. Occurrence intensity of AM Fungi associated with Phoenix dactylifera L

\begin{tabular}{|l|l|l|l|l|}
\hline Sr no. & $\begin{array}{l}\text { Plant } \\
(\text { Phoenix } \\
\text { dactylifera L. })\end{array}$ & $\begin{array}{l}\text { Occurrence intensity } \\
\text { of AM Fungi } \\
\text { Vesicles }\end{array}$ & Arbuscules & $\begin{array}{l}\text { Percentage root } \\
\text { colonization (\%) }\end{array}$ \\
\hline 1 & Sample 1-Madhapar & ++ & + & 74 \\
\hline 2 & Sample 2-Reladi & + & + & 31 \\
\hline 3 & Sample 3-Anjar & ++ & + & 43 \\
\hline $\begin{array}{l}(+=1-25 \%: \text { Poor ; ++ = 25-50\%: Good ; +++ = 50-75\%: Moderate ; ++++ = more than } \\
75 \%: \text { Excellent ; - = Absent }) .\end{array}$
\end{tabular}

Table 2: Physical analysis of Rhizospheric soil

\begin{tabular}{|l|l|l|l|l|l|}
\hline Sr. no. & $\mathrm{pH}$ & $\begin{array}{l}\text { Moisture content } \\
(\%)\end{array}$ & $\begin{array}{l}\text { Water Holding } \\
\text { Capacity (WHC) } \\
(\%)\end{array}$ & $\begin{array}{l}\text { Bulk density } \\
\left(\mathrm{gm} / \mathrm{cm}^{3}\right)\end{array}$ & $\begin{array}{l}\text { Porosity } \\
(\%)\end{array}$ \\
\hline Sample-1 & 7.5 & 5.54 & 90.81 & 1.20 & 65 \\
\hline Sample-2 & 8 & 4.75 & 89.8 & 1.15 & 54 \\
\hline Sample-3 & 8 & 10.38 & 90.9 & 1.16 & 58 \\
\hline
\end{tabular}

pH Range Soil Reaction Rating as given by Department of Agriculture, Government of India

$<4.6=$ Extremely acid; 4.6-5.5 = Strongly acid; 5.6-6.5 = Moderately acid; 6.6-6.9 = Slightly acid; 7.0 = Neutral; 7.1-8.5 = Moderately alkaline; >8.5 = Strongly alkaline. 


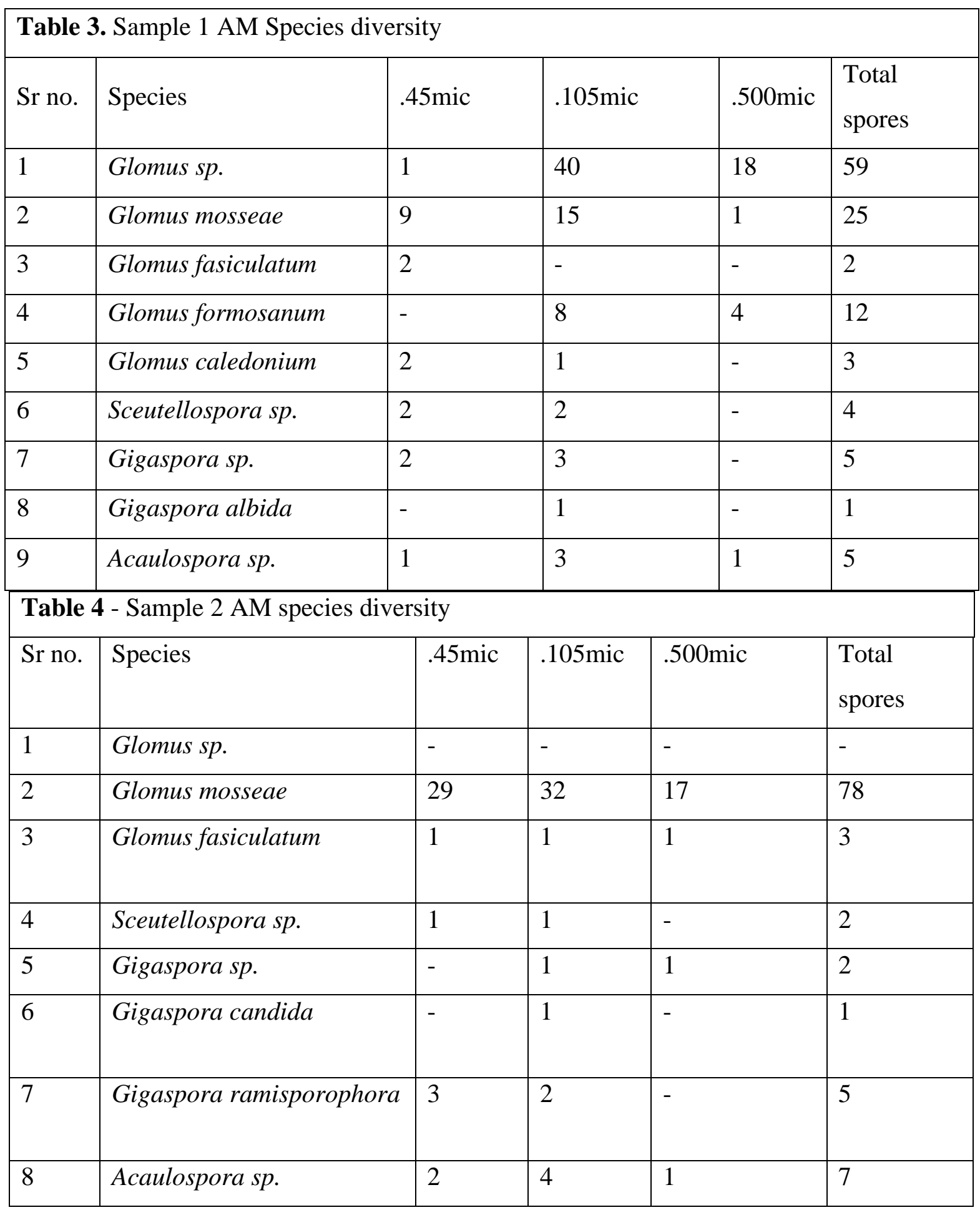




\begin{tabular}{|c|c|c|c|c|c|}
\hline Sr no. & Species & $.45 \mathrm{mic}$ & $.105 \mathrm{mic}$ & $.500 \mathrm{mic}$ & $\begin{array}{l}\text { Total } \\
\text { spores }\end{array}$ \\
\hline 1 & Glomus sp. & 1 & - & - & 1 \\
\hline 2 & Glomus mosseae & 95 & 88 & 4 & 187 \\
\hline 3 & Glomus aggregatum & - & 7 & - & 7 \\
\hline 4 & Glomus formosanum & 6 & - & - & 6 \\
\hline 5 & Glomus caledonium & - & 2 & - & 2 \\
\hline 6 & Glomus monosporum & 1 & 1 & - & 2 \\
\hline 7 & Sceutellospora sp. & 17 & - & - & 17 \\
\hline 8 & Gigaspora sp. & 1 & - & - & 1 \\
\hline 9 & Gigaspora albida & 4 & - & - & 4 \\
\hline 10 & Gigaspora candida & 1 & - & - & 1 \\
\hline 11 & Gigaspora ramisporophora & 5 & 1 & - & 6 \\
\hline 12 & Acaulospora sp. & 15 & 1 & - & 16 \\
\hline 13 & Sclerocystis sp. & - & 1 & - & 1 \\
\hline
\end{tabular}




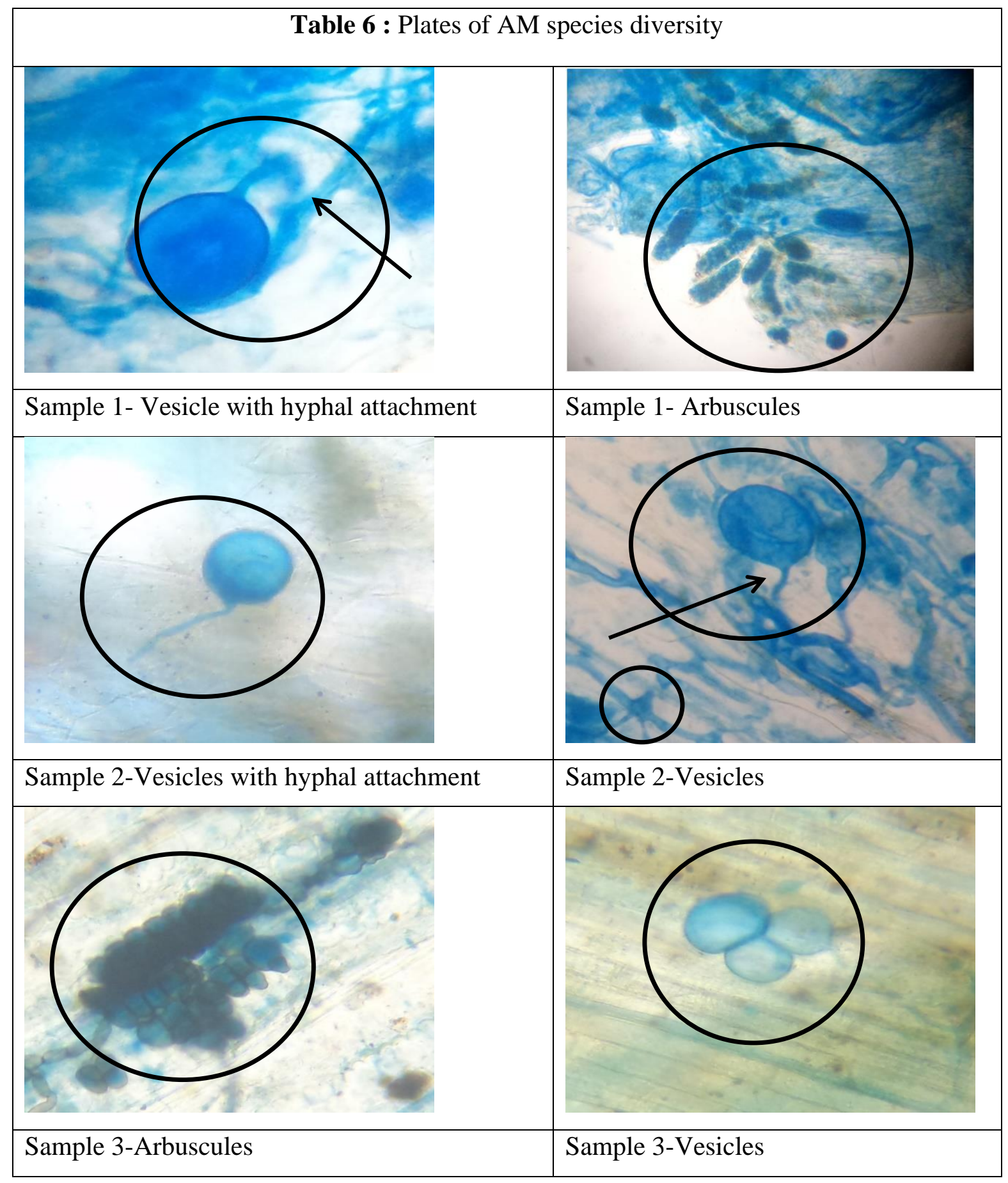




\section{REFERENCES}

[1]. Abdelhak M, Guendez E, Eugene K, Kefalas P (2005) Phenolic profile and antioxidant activity of the Algerian ripe date palm fruit (Phoenix dactylifera). Food Chem; 89: 411-420.

[2]. Abdul, A, Allaith A.(2008) Antioxidant activity of Bahraini date palm (Phoenix dactylifera L.) fruit of various cultivars Int J Food Sci Technology,; 43:1033-1040.

[3]. Ahmed AI, Ahmed AWK, Robinson, RK (1995) Chemical composition of date varieties as influenced by the stage of ripening Food Chem; 54: 305-309.

[4]. Al Farsi MA, Alasalvar C, Morris A, Baron M, Shahidi, F (2005) Compositional and sensory characteristics of three native sun-dried date (Phoenix dactylifera L.) varieties grown in Oman. J Agric Food Chem; 53:7586-7591.

[5]. Al Farsi MA, Lee CY. (2008) Nutritional and functional properties of dates: a review Critical Reviews. Food Sci Nutr; 48:877-887.

[6]. Al-Qarawi A, Abdel-Rahman H, Ali BH, Mousa HM, El-Mougy SA, Al-Shahib W, Marshall RJ (2003).The fruit of the date palm: its possible use as the best food for the future? Int J Food Sci Nutr; 54(4): 247-259.

[7]. Al-Whaibi, M.H., and Khaleil, A.S (1994). The effect of $\mathrm{Mg}$ on $\mathrm{Ca}, \mathrm{K}$ and $\mathrm{P}$ content of date palm seedlings under mycorrhizal and nonmycorrhizal condtions. Mycoscience; 35: 213217.

[8]. Barea, J.M., Jeffries, P (1995) Arbuscular mycorrhzae in sustainable soil- plant systems. In: Varma, A., Hock, B. (Eds.), MycorrhizaStructure, Function Molecular Biology, and Biotechnology. Springer, Berlin; 875.

[9]. Chatila R, West AB (1996) Hepatomegaly and abnormal liver tests due to glycogenosis in adults with diabetes. Medicine; 75: 327-333.

[10]. El-Beltagy AE, Nassar AG, El-Ghobashy AK, Yousef HYM (2009) Microwave a potent date syrup producing method Egypt J Appl Sci; 24 (8B): 454-464.

[11]. Fadoua Sghir1, Jihane Touati1, Mohamed Chliyeh1, Amina Ouazzani Touhami1, Abdelkarim Filali Maltouf2, Cherkaoui El Modafar3, Ab-del majid Moukhli4, Ahmed Oukabli5, Rachid Benkirane1, and Allal DouiRa1, ( 2015) Diversity of arbuscular mycorrhizal fungi in the rhizosphere of date palm tree (Phoenix dactylifera) in Tafilalt and Zagora regions (Morocco), The Ame J Sci \& Med Res.Fayadh JM, Al-Showiman, SS. (1990) Chemical composition of date palm (Phoenix dactylifera L.) J Chem Soci Pakistan; 12: 84-103.

[12]. Fisher \& Jayachandran (2008) Beneficial Role of Arbuscular Mycorrhizal Fungi on Florida Native Palms: Mycorrhiza Vol. 52(3).

[13]. Francis, R. and Read, D.J (1984) Direct transfer of carbon between plants connected by vesicular-arbuscular mycorrhizal mycelium Nature; 307: 53-56.

[14]. Gad AS, Kholif AM, Sayed AF (2010). Evaluation of the nutritional value of functional yogurt resulting from the combination of date palm syrup and skim milk Am J Food Technology; 5 (4): 250-259.

[15]. Giachini A., Oliveira V. L., Castellano M. A., et Trappe J. M., (2000). Ectomycorrhizal fungi in Eucalyptus and Pinus plantations in southern Brazil. Mycologia, 92 (1-6): 1166-1177.

[16]. Goodwin, J. (1992) The role of mycorrhizal fungi in competitive interactions among native bunchgrasses and alien weeds: A review and synthesis Northwest Science; 66(4): 251-260.

[17]. Harrison SA, Brunt EM, Goodman ZD, Di Bisceglie AM ((2006) Diabetic hepatosclerosis: diabetic microangiopathy of the liverArch. Pathol and Lab Med; 130: 27-32.

[18]. J. J. Shah, Emir. J. Food Agriculture (2014) Date palm cultivation in India: An overview of activities Desert. Jodhpur (India): Scientific Publishers;26 (11): 987-999 
[19]. J. Ramoliya \& A. N. Pandey (22 Mar 2010) Soil salinity and water status affect growth of Phoenix dactylifera seedlings P. ISSN: 0114-067

[20]. Jaiti, F., A. Meddich, I. El Hadrami,(2007). Physiological and Molecular Plant Pathology, 71: 166.

[21]. Jayaa S. Pawaar, Umesh B. Kakde (2013) Study on mycorrhizal symbiosis with date palm on stability and vegetative growth traits Esmaeilifar, Ali Vol., 5 (2), 160-167.

[22]. Kiritoshi S, Nishikawa T, Sonoda K, Kukidome D, Senokuchi T, Matsuo T, Matsumura T, Tokunaga H, Brownlee M, Araki E (2003) Reactive oxy-gen species from mitochondria induces cyclooxygenase-2gene expression in human mesangial cells: potential role in diabetic nephropathy Diabetes; 52: 2570-2577.

[23]. Levinthal GN, Tavill AJ (1999) Liver disease, and Diabetes Mellitus. Clin Diabetes; 17: 73.

[24]. Manassah, J.M., Briskey, E.J. (Eds.) (1981) Advances in Food-Producing Systems for Arid and Semiarid Lands. Academic Press, New York; 581-600

[25]. Marchesini G, Brizi M, Bianchi G. ( 2001) Nonalcoholic fatty liver disease A feature of metabolic syndrome. Diabetes; 50: 1844-1850.

[26]. McLennan SV, Heffernan S, Wright L (1991) Changes in hepatic glutathione metabolism in diabetes. Diabetes; 40: 344-348.

[27]. Mohamed H. Al-Whaibi (October 2009) Diversity of arbuscular mycorrhizal fungi in the rhizosphere of date palm tree (Phoenix dactylifera) in Tafi-lalt and Zagora regions (Morocco) Journal of pure and applied microbiology; Vol. 3(2).

[28]. Muthukumar $\mathrm{T}$ and Udaiyan K (2002) Arbuscular mycorrhizal fungal composition in semi-arid soils of Western Ghats, southern India: Curr. Sci, 82 (6): 25: 624-628.

[29]. Nakanishi N, Shiraishi T, Wada M (2005) Association between fasting glucose and C- reactive protein in a Japanese population. The Minoh study, Diab Res Clin Pract; 69: 88-98.

[30]. Nishikawa T, Edelstein D, Du XL, Yamagishi S, Matsumura T, Kaneda Y, Yorek MA, Beebe D, Oates PJ, Hammes HP, Giardino I, Brownlee $\mathrm{M}(2000)$ Normalizing mitochondrial superoxide production blocks three pathways of hyperglycaemic damage Nature; 404: 787-790.

[31]. Peter J Jeffries, Silvio Gianinazzi, Silvia Perotto (2002) The contribution of Arbuscular Mycorrhizal Fungi in sustainable maintenance of plant health and soil fertility Springer.

[32]. Prakash L. Patel, Nirmal P. Patel, Prakash H. Patel, Anita Gharekhan (2014) Correlation study of soil parameters of Kutch district Agriculture land International Journal of Scientific and Research Publications; Volume 4, Issue 5, ISSN 2250-3153.

[33]. Bouamri R, Dalpe Y, Serrhini MN (2006) Arbuscular mycorrhizal fungi species associated with rhizosphere of Phoenix dactylifera L. in Morocco Bennani African Journal of Biotechnology Vol. 5 (6), pp. 510-516,

[34]. Sing R.S. and Murlidharan C.M. ICAR,Bikaner \& SDAU Mundra (2016) Genetic Diversity and Sustainability of Date palm (Phoenix dactylifera) in Arid Region, Compedium 145155.

[35]. Saleh EA, Tawfik MS, \& Abu-Tarboush HM (2011) Phenolic contents and anti-oxidant activity of various date palm (Phoenix dactylifera L.) fruits from Saudi Arabia Food Nutri Sci; 2:1134-1141.

[36]. Sattar N, Scherbakova O, Ford I, O'Reilly DS, Stanley A, Forrest E, Macfarlane PW, Packard CJ, Cobbe SM, Shepherd J (2004) Elevated alanine aminotransferase predicts new-onset type 2 diabetes independently of classical risk factors, metabolic syndrome, and C-reactive protein in the West of Scotland coronary prevention study. Diabetes; 53: 2855-2860. 
[37]. Saxena AK, Srivastava P, Kale RK, Baquer NZ (1993) Impaired antioxidant status in diabetic rat liver Effect of vanadate. Biochem Pharmacol; 45(3):539-42.

[38]. Schubler, A., Schwarzott, D. and Walker, C. (2001) A new fungal phylum, the Glomeromycota: phylogeny and evolution. Mycological Research; 105: 1413- 1421.

[39]. Selvaraj, T., P. Chelleppan (2006) Arbuscular mycorrhizae: a diverse personality, Centrai Eur. J. 7: 349-358..

[40]. Syeda Sadia Bokhari, samrah Tariq, Syed abid ali, viqar sultana, jehan ara, and syed ehteshamul-haque (2014) Management of root rot and root knot disease of mungbean with the application of mycorrhizospheric fluorescent pseudomonas under field condition Pak. J. Bot., 46(4): 1473-1477.

[41]. Titus, J.H., Leps, J (2000) The response of arbuscular mycorrhizae to fertilization, mowing, and removal of dominant species in a diverse oligo-trophic wet meadow. American Journal of Botany; 87: 392-401

[42]. Trappe R J.M (1979) Mycorrhiza-nodule-host interrelationships in symbiotic nitrogen fixation: a quest in need of questers. ln : Symbiotic Nitrogen Fixation in the Management of Temperate Forests, J.C. Gordon, C.T. Wheeler and D.A. Perryeds, Oregon State University Forest Research Laboratory, Corvallis, Oregon.

[43]. Vayalil PK.( 2012) Date fruits (Phoenix dactylifera Linn): An emerging medicinal food. Crit Rev in Food Sci Nutri; 52: 249-271.

\section{Cite this article as :}

Dipika J. Dalal, Hitesh Solanki, "Arbuscular Mycorrhizal Fungi : Diversity and Its Impact with Abiotic Factors in Phoenix dactylifera L. of Kachchh Region, Gujarat, India", International Journal of Scientific Research in Science and Technology (IJSRST), Online ISSN : 2395-602X, Print ISSN : 23956011, Volume 8 Issue 2, pp. 125-135, March-April 2021. Available at

doi : https://doi.org/10.32628/IJSRST218222

Journal URL : https://ijsrst.com/IJSRST218222 